\title{
Retoryczny post, czyli wielka kariera pewnego przedrostka
}

\begin{abstract}
Streszczenie:
Celem artykułu jest analiza sposobu postrzegania post-prawdy przez dziennikarzy największego polskiego portalu prawicowo-konserwatywnego wPolityce.pl. Autor, wychodząc od definicji opublikowanej na stronie internetowej słownika oksfordzkiego, rozważa ewentualne uspółzależności tego neologizmu z innymi uyrażeniami zaczynającymi się prefiksem post-, zułaszcza z postmodernizmem. Relacja ta okazuje się szczególnie istotna ze uzględu na możliwość wykorzystania obu wyrażeń jako narzędzi retorycznych.
\end{abstract}

Słowa kluczowe: post-prawda, postmodernizm, retoryka, wPolityce.pl.

\section{At rhetorical post i.e. a great career of a little prefix}

\section{Abstract:}

The purpose of this article is the analysis of the way the journalists of the biggest Polish righist-conservatist portal polityce.pl perceive post-truth. He author starts with the Oxford dicionay definition considers the potential correlation of the above mentioned neologism with Rother expressions strating with the prefix post-, especially postmodernizm. That relationship seems of particular importance due to the possibiliy of using both expressions as rheorical devices. Key words: post-truth, postmodernism, rhetoric, wPolityce.pl

\section{Zamiast wstępu}

Pierwotny tytuł tego artykułu miał brzmieć bardziej prowokacyjnie Wielki post, czyli retoryczna konstrukcja wroga $w$ mediach konserwatywnych. Jednakże w kwietniu 2017 roku, w ramach serii „Niezbędnik Inteligenta”, ukazało się specjalne wydanie tygodnika „Polityka”, które zatytułowano bardzo podobnie: „Wielkie post”. Wydawnictwo to zostało podzielone na cztery części poprzedzone prologiem pt. „Kryzys rzeczywistości.” Pierusza część dotyczyła kategorii prawdy, druga uyznaczała najważniejsze współczesne pola kryzysu (tożsamości, postępu, państua, wartości), część trzecią stanowiła „Mała encyklopedia post”, obejmująca post-politykę, post-świeckość, post-wzrost, post-kapitalizm, post-modernizm, post-humanizm. Ostatni rozdział zatytułowany „W poszukiwaniu projektu” zamyka artykuł pt. Odzyskiwanie sensu, w którym Edwin Bendyk przekonuje: 
Popularność post-prawdy to symptom kryzysu rzeczywistości, w którym pojęcia stosowane w codziennym życiu u coraz mniejszym stopniu odpowiadają doświadczeniom pojedynczych osób i całych społeczności. W rezultacie ustaje możliwość racjonalnego porozumieuania się, społeczną komunikację opanouują emocje, miejsce dialogu zajmuje przemoc. Nie jesteśmy jednak na post-prawdę skazani. Jeszcze nie ${ }^{1}$.

Simon Jenkins - publicysta angielskiego „The Gauridan” - widzi światełko nadziei w komunikacji internetowej, która w przyszłości ma obalić kłamstwa nieuczciuych polityków ${ }^{2}$. Autor tego artykułu postanowił zbadać, jak postrzegana jest post-prawda właśnie w Internecie. Wychodząc od ustaleń redaktorów słounika oksfordzkiego, którzy łączą popularność terminu post-prawda z sukcesami wyborczymi partii konserwatywno-prawicowych, jako materiał badawczy wybrano najbardziej popularny polski serwis internetowy o takim ułaśnie profilu - wPolityce.pl.

Przekładając to na język naukowy, należy uznać, że tezą niniejszego artykułu jest przekonanie o retorycznym uykorzystywaniu wyrażeń zaczynających się od przedrostka post- (post-prawda, postmodernizm) jako kategorii pojęć nienawistnych, niezależnie od ich słownikowego znaczenia. Prefiks ten stał się nośnikiem negatywnych treści i emocji, które tworzą jeden z głównych ideografów serwisu wPolityce.pl. Kategorią doboru analizowanych treści stała się obecność wyrażeń postprawda ${ }^{3}$ i postmodernizm w artykułach wskazanych przez wyszukiwarkę badanego serwisu. Wśród pytań badawczych najważniejsze to: jak definiowane są oba pojęcia przez dziennikarzy serwisu, jakie zależności uystępują między uyrażeniami postprawda i postmodernizm, w jaki sposób prefiks post- upływa na znaczenie następujących po nim wyrazów, czy wyrażenia te pełnią funkcje perswazyjne.

\section{Skąd się wzięła post-prawda?}

Światową karierę wyrażanie post-prawda zrobiło w 2016 roku, kiedy zostało wybrane przez redakcję słownika oksfordzkiego najważniejszym terminem roku. W uzasadnieniu tej decyzji można przeczytać, że sformułowanie to odnosi się do sytuacji, w której emocje oraz osobiste przekonania odgrywają większą rolę $\mathrm{w}$ kształtowaniu opinii publicznej niż obiektyune fakty4. W takim znaczeniu wyrażanie to zostało opublikowane po raz pieruszy w 1992 roku, w artykule Steviego Tesicha pt. Rząd kłamstw, na łamach amerykańskiego magazynu „The Nation”․ Przed 2016 rokiem termin ten pojawiał się

\footnotetext{
${ }^{1}$ E. Bendyk, Odzyskiwanie sensu, http://www.polityka.pl/niezbednikinteligenta/1699648,1,czy-jestesmy-skazani-na-post-praude.read (dostęp: 20.04.2017).

2 S. Jenkins, Post-truth politics will be debunked by online facts, https://wuw.theguardian. com/commentisfree/2017/jan/26/post-truth-politics-online-facts-donald-trump-lies (dostęp: 30.04.2017).

${ }^{3}$ Na stronach serwisu wyłącznie pisounia łączna.

${ }^{4}$ Word of the year 2016, https://en.oxforddictionaries.com/word-of-the-year/word-of-the-year-2016 (dostęp: 12.04.2017).

5 S. Tesich, A Government of Lies, „The Nation” 1992 (January), s. 6-13.
} 
tylko kilkakrotnie w mediach. Wśród nielicznych publikacji, które w ten sam sposób definiowały interesujące nas pojęcie, wymienia się książkę The Post-truth Era Ralpha Keyesa z 2004 roku. Autor charakteryzował tam uspółczesność jako czas, w którym kłamstwo stało się uszechobecnym elementem naszej rzeczywistości. Keyes mnoży przykłady nadużyć wobec rzeczywistości. Okazuje się, że kłamią wszyscy, jednak nikt nie chce się do tego przyznać. Dlatego w pouszechnym użyciu znalazły się wyrażenia maskujące ten proceder - pozbawiając go etycznego ciężaru. Zamiast kłamać „wyrażamy się niedokładanie”, „przesadzamy”, zdarza się nam „mieć mylny osąd sprawy” lub nawet „kręcić”. Czasem po prostu „nie jesteśmy do końca szczerzy” lub okazuje się, że w danej sprawie „została popełniona pomyłka”. Wszystkie te eufemizmy stały się szczególne użyteczne w polityce. Funkcjonująca w poprzednich epokach binarna opozycja prawda - kłamstuo została rozmyta przez trzecią kategorię - post-prawdę, która niweluje dwie poprzednie. Fakty - a właściwe ich weryfikowalność - przestają być istotne. Ważniejsze okazuje się umieszczenie wypowiedzi w określonym kontekście. Jej siła opiera się na zbieżności z preferencjami słuchaczy - co nadaje jej status wiarygodności. Dodatkowym kryterium jest autorytet mówcy. Powołany do życia qausi-fakt, czy może lepiej napisać: fakt medialny, żyje swoim życiem, zaspokajając oczekiwania uybranej części społeczeństwa. Trudno bowiem uwierzyć, by politycy kłamiąc w kwestiach, które z łatwością można zweryfikować, chcieli zdobyć nowych zuolenników. Kiedy Donald Trump ogłosił, że inauguracja jego prezydentury ściągnęła więcej ludzi niż inauguracja prezydentury Obamy (wbrew danym liczbouym, zapisom wideo etc.), w rzeczywistości mówił do swojego elektoratu, realizując w ten sposób jego emocjonalne oczekiwania. Mimo że wypowiedź ta miała cechy konstatacji i jako taka może podlegać kategoriom prawdy i fałszu, jej wartość opierała się na innych przesłankach - przede uszystkim istotna była jej moc illokucyjna. W tym kontekście można ją badać podobnie jak wypowiedzi performatywne - bowiem jej celem jest stuorzenie peunej rzeczywistości. Oczywiście nie chodzi tu o świat zeunętrzny, lecz o sposób jego postrzegania i oceniania.

Grunt dla post-prawdy przygotowała postępująca tabloidyzycja, która w krótkim czasie z mediów przeniosła się na politykę. Podobnie jak u przypadku tabloidów, zarówno nadawca post-prawdy, jak i odbiorcy operują w ramach jednej ustalonej konwencji i sankcjonują wzajemnie jej reguły. Najważniejszą z nich jest właśnie uspólny sposób postrzegania rzeczywistości i upisana u nią nieufność wobec elit. Kuestie prawdziwości i rzetelności zastępuje uzględna wiarygodność poparta autorytetem nadawcy, którego poglądy są tożsame z poglądami odbiorców. Poszczególne przykłady rozmijania się z prawdą zdają się usprawiedliwione pewną całościową koncepcją, która apriorycznie jest uznawana za słuszną i prawdziwą. W ten sposób prawda przestaje być kategorią niezależną i zewnętrzną, i jako taka staje się właśnie post-prawdą - rzeczywistością przesączoną przez pryzmat emocji i ideologii, w której

${ }^{6}$ R. Keyes, The Post-Truth Era: Dishonesty and Deception in Contemporary Lifes, St. Martin's Press, New York 1992. 
fakty ustępują miejsca domniemaniom, insynuacjom czy świadomym kłamstwom. Zułaszcza te ostatnie uymagają retorycznej rehabilitacji. Zmiana nazuy i urzucenie do większego worka semantycznego niweluje negatywne konotacje. Era post-prawdy to okres, w którym znika polaryzacja między prawdą i kłamstuem. Jest to kolejny etap degradacji platońskiej triady, w której piękno, dobro i prawda miały się uzupełniać. O ile złudzenia co do piękna w polityce straciliśmy już dawno, o tyle związek dobra i prawdy do niedawna wydawał się niepodważalny. W układzie nowoczesnych wartości kłamstwo, jako przeciwieństwo prawdy, było złe. Jednak ponowoczesność przewróciła w końcu aksjologiczną drabinę, pozbawiając sensowności samą uspinaczkę.

Jak zauważył Adam Chmieleuski „termin «kłamstwo», choć zachował zdolność opisywania pewnych zachowań ludzkich, w polityce utracił swoją dotychczasową siłę sprauczą. Tym samym kłamstuo, które jeszcze niedawno miało krótkie nogi, skończyło się. Zastąpiła je post-prawda"7. Niestety problematyczna też okazuje się kategoria prawdy. Jej ujawnienie nie zmienia rzeczywistości tak, by była w stanie odwrócić skutki wywołane przez fałszywe sądy - nie prowadzi ani do dymisji, ani nawet do przeprosin. Prawda nie wyzuala. W natłoku wiadomości staje się ona jedynie kolejnym neusem. Post-prawda jest powszechna i jako taka ulega naturalizacji (tak jak sensacyjne nagłówki tabloidów czy pojawiające się co jakiś czas na ich łamach informacje o UFO), stając elementem naszej codzienności.

\section{Od postmodernizmu do post-prawdy}

Oprócz oczywistego spowinowacenia poprzez przedrostek post-prawdę, postmodernizm i ponowoczesność łączą negatywne konotacje (zwłaszcza w analizowanych tu mediach konserwatywnych) oraz domniemany stosunek do tradycyjnych wartości. W tym miejscu trzeba jednak zurócić uwagę na funkcjonujące $w$ języku polskim rozgraniczenie na postmodernizm i ponowoczesność (ang.: postmodernism, postmodernity). Wielu badaczy zuracało uwagę na chaos terminologiczny w tej kuestii, trudność wyznaczenia granic czasowych oraz stosunek do słowa występującego po prefiksie post-.

Anthony Giddens zaproponował, by terminu postmodernizm, w odróżnieniu od ponowoczesności, używać do nazywania stylów i prądów w literaturze, sztuce i architekturze, które odnoszą się do „refleksji estetycznej o naturze nowoczesności”. Według socjologa nowoczesność nie jest jeszcze projektem zamkniętym ${ }^{9}$. Pod koniec XX wieku nastąpiła jej radykalizacja (zbyt pochopnie nazwana przez filozofów ponowoczesnością), wśród jej przejawów Giddens wymienia: dezintegracje ewolucjonizmu, zanik teleologii

\footnotetext{
7 A. Chmieleuski, Post-prawda i populizm prawdziwościowy, http://www.academia. edu/31567577/POST-PRAWDA_I_POPULIZM_PRAWDZIWO\%C5\%9ACIOWY_1 (dostęp: 20.04.2017).

${ }^{8}$ A. Giddens, Konsekwencje nowoczesności, Wydawnictwo Uniwersytetu Jagiellońskiego, Kraków 2008, s. 32.

${ }_{9}^{9}$ Por. E. Barańska, Kultura ponowoczesna w myśli Baumana, Wydaunictwo Adam Marszałek, Toruń 2016, s. 183-188.
} 
historii, uszechobecną i przenikającą uszystkie dziedziny refleksyjność oraz zanik dominującej pozycji zachodu ${ }^{10}$.

Co do funkcjonalności określenia ponowoczesność wątpliwości miał też Zygmunt Bauman. W swoich późniejszych pracach zastąpił je płynna nowoczesnościa, tym samym zuracając uwagę na zakorzenienie uspółczesności u dorobku nowoczesności, przy jednoczesnym rozmyciu jej granic. Nie uchodząc u szczegóły obu koncepcji, dla nas istotne jest to, co przeszkadzało obu myślicielom $w$ posługiwaniu się terminem postmodernity. Problematyczny okazał się ułaśnie prefiks post- [coś co następuje po], który u tym przypadku nie oznacza następstwa czasowego (zwracają na to także uwagę autorzy słownika oksfordzkiego w przypadku wyrażenie post-truth) - tylko właśnie rodzaj przesilenia, który powoduje rozmycie podstaw wyznaczających pierwotne idee nowoczesności. W tym sensie przedrostek post-, wbrew swojemu słounikowemu znaczeniu oraz postulatom wspomnianych myślicieli, stał się znakiem zepsucia i schyłku. Jako taki przypomina on nowotwór, który po doklejeniu do pierwotnego terminu niemalże całkowicie zmienia jego charakter, pozostawiając na końcu groteskoue truchło pierwotnej idei (post-prawda jest karykaturą prawdy, a postmodernizm modernizmu). W takim znaczeniu objawia się właśnie jego wielka retoryczna kariera w mediach konserwatywnych. Przedrostek post- niesie ze sobą znamiona ocenne. Post-prauda stanowi narzędzie i konsekwencję ponowoczesności ${ }^{11}$. Ta zaś dla publicystów prawicowych oznacza przede uszystkim upadek tradycyjnych wartości. Potwierdzeniem tej relacji mają być analizy i diagnozy, których autorami byli czołowi badacze ponowoczesności. Pomija się niemalże całkowicie fakt, że kłamstwo w polityce istniało na długo przed jej nadejściem ${ }^{12}$, sama zaś post-prawda definiowana jest najczęściej u odniesieniu do retoryki polityków reprezentujących partie prawicowo-konserwatywne.

W wielu przypadkach publicyści bezpośrednią winą obarczają samych filozofów traktując ich jak agitatorów i propagandystów siejących defetyzm. Zarazem jednak nie sposób pominąć faktu, że kluczouymi hasłami, poprzez które interpretuje się ponowoczesność, są zwątpienie i relatywizm, obejmujące także kategorie prawdy.

Tu na pieruszy plan wysuwają się prace Francisa Lyotarda. Już w 1979 roku w swojej książce Kondycja ponowoczesna. Raport o stanie wiedzy $y^{13}$ ogłosił on upadek wielkich narracji. Owe wielkie narracje to opowieści, które miały kształtować nowożytny sposób pojmowania rzeczywistości i porządkować uspólne dzieje. Stanowią

10 Ibidem, s. 37.

11 „Modny jest teraz termin «postprawda». Nawiązuje oczywiście do postmodernizmu, który od dekad ma ogromny upływ na środowiska intelektualne i artystyczne. Niby nic nowego, z tym że dzięki internetowi, a zułaszcza portalom społecznościouym, postmodernizm zszedł do mas. Elity lewicowo-liberalne od lat głosiły, że nic już nie jest pewne, nie ma twardych wartości i punktów odniesienia, świat ciągle się zmienia, więc «czymże jest prauda?». Jednak gdy taka postawa się upouszechniła, kategoria prawdy stała się nagle dla tych samych elit punktem odniesienia" - M. Herman, http://niezalezna.pl/96695-internet-zaczyna-zjadac-wlasny-ogon (dostęp: 07.04.2017).

12 Por. A. Chmieleuski, op. cit.

${ }^{13}$ F.J. Lyotard, Kondycja ponowoczesna. Raport o stanie wiedzy, Fundacja Aletheia, Warszawa 1997. 
pewną oś, schemat, dzięki któremu można objąć i uzasadnić historię oraz rozwój społeczeństwa. Legitymizują one i łączą w jedną całość mniejsze opowieści, lokując rozwój poszczególnych dziedzin w większym porządku, którego spoiwem jest wspólny cel. Kontekstem dla tych opowieści jest właśnie przekonanie o istnieniu jakiegoś punktu końcowego, który zmieni oblicze całej ludzkości. W Kondycji ponowoczesnej Lyotard uyróżnia dwie wielkie narracje. Obydwie mają charakter metafizyczny.

Pierusza z nich to opowieść wolnościowa. Narracja ta opowiada rewolucyjną historię emancypacji metafizycznie pojmowanego ludu, dla którego nauka ma być jednym ze środków do uzyskania wolności. Zuieńczeniem tej drogi ma być wolność wyrażająca się w pełnym dostępie do edukacji i udziale w demokratycznej władzy.

Druga wielka narracja to tak zwana opowieść spekulatywna, w której centrum zainteresowania znalazł się Duch w swojej dążności do samowiedzy. Jednym z przejawów tej tendencji jest mnożąca się w dobie nowoczesności ilość odkryć i wynalazków. Opowieść spekulatywna to droga do poznania prawdy, ale i wytyczna, która sankcjonuje celowość ouych wysiłków. Jednakże w XX wieku narracja ta okazuje się nie tylko niekoherentna, lecz także po prostu zbędna. Filozoficzna podstawa, która miała syntetyzować poszczególne kierunki badań, traci rację bytu. Opowieść nie jest w stanie połączyć i uzasadnić nauki, sama również nie znajduje uzasadnienia. W dążeniu do poznania ważniejsze staje się praktyczne zastosowanie nauki. Cząstkowe cele, ich praktyczna siła i możliwość bezpośredniego zastosowania stają się wystarczającą legitymizacją dla siebie.

Krytycznym momentem, dekonstruującym jakąkolwiek zasadność metanarracji jest Holocaust. Nowoczesny projekt kończy się ludobójstwem ${ }^{14}$. W obliczu ogromu zbrodni nazistouskich Lyotard zadaje pytanie o wiarygodność wielkich narracji. Ich kres nie oznacza jednak całkowitego końca opowieści uzasadniających, istnieje bowiem sieć mniejszych narracji, które idąc w różnych kierunkach, krzyżują się czasami, tworząc cząstkowe narracje dziejów. Nie obejmują jednak one nigdy całości, często podlegając wpływom społecznym i politycznym. Jako takie nie dają one gwarancji oparcia w prawdzie - pojmowanej jako zewnętrzna. Bardziej użyteczna bowiem staje się tu prawda historyczna.

Możliwość dotarcia do prawdy zewnętrznej została podważona także przez Richarda Rorty'ego, który twierdził że „rzeczywistość ma się w przeważającej mierze nijak do naszych jej opisów i że ludzka jaźń poustaje w procesie użytkowania słounika, a nie zostaje u nim trafnie bądź nie trafnie uyrażona" ${ }^{15}$. W takim ujęciu pojęcie praudy zdaje się wytyczną naszego postrzegania i kompetencji językouych.

Należy odróżnić twierdzenie, że śuiat jest na zewnątrz, od twierdzenia, że prauda jest na zeunątrz [...] Śuiat jest na zewnątrz, nie ma tam jednak opisów świata. Tylko opisy śuiata

${ }_{14}$ F.J. Lyotard, Postmodernizm dla dzieci. Korespondencja 1982-1985, Fundacja Aletheia, Warszawa 1998, s. 31-32.

${ }^{15}$ R. Rorty, Przygodność, ironia i solidarność, Wydawnictuo W.A.B, Warszawa 1996, s. 23. 
mogą być prawdziue bądź fałszywe. Świat sam w sobie nie usparty opisową działalnością istot ludzkich - taki być nie może ${ }^{16}$.

Najpełniejszy kontekst filozoficzny dla ery post-prawdy tworzy koncepcja Jeana Badrillarda. Opisana przez niego na początku lat 80. XX wieku hieperzeczywistość zdaje się najlepiej relacjonować uspółczesne zagubienie człowieka. Symulakry i symulacja opowiadają o prawdzie i rzeczywistości, a właściwie o ich braku. Jako motto dla swojego dzieła Baudrillard wybrał fragment przypisywany Koheletowi (fragment ten, a właściwie jego autorstwo, w rzeczywistości jest mistyfikacją, przytoczony w tym miejscu przez Baudrillarda staje się właśnie symulakrem): „Obraz nigdy nie jest tym, co skrywa prawdę - to prawda skrywa to, że jej nie ma. Obraz jest prawdziwy"17. W tej pesymistycznej wizji prawda nie ma żadnego znaczenia, w natłoku informacji człowiek nie potrafi oddzielić rzeczy ważnych od błahych, prawdy od kłamstwa. Demokracja, jaką znamy, ma niewiele uspólnego z pierwotną ideą. Władza ludu jest fikcją. Kolejne afery i skandale w rzeczywistości nie mają na celu demaskowania naruszeń prawa, a jedynie utrwalanie przekonania o jego uszechobecności - ,jest to wskrzeszanie i moralnych i politycznych zasad, a za sprawą wyobrażenia - regeneracja zagrożonej zasady rzeczywistości. Ujaunienie skandalu zausze stanowi hołd złożony prawu"18. Rządy krajów rozwiniętych wypracowały system narzędzi dyskursywnych, których podstawowym zadaniem jest ułaśnie utrzymywanie mistyfikacji ${ }^{19}$.

Z resztą sam Demos, zachłystnięty „demokracją statusu, demokracją telewizji, samochodu i zestawu stereo" ${ }^{20}$, zdaje się nie być zainteresowany odkryciem prawdy. Podstawową takiej demokracji nie jest wolność czy równość - tylko pouszechny dostęp do dóbr konsumpcyjnych, którego widocznym znakiem jest tak zwany amerykański styl życia ${ }^{21}$.

Winą za obecny stan rzeczy obarcza francuski socjolog przede uszystkim media, które pod pozorem zwierciadła życia zmodyfikowały nasz sposób percepcji, do tego stopnia, że nasza ocena rzeczywistości, całkowicie zapośredniczona jest u przekazie medialnym. Rzeczywistość z ekranu zdaje się pełniejsza i prawdziusza niż ta widziana własnym wzrokiem ${ }^{22}$. Media nie tylko uczą nas jak postrzegać rzeczywistość, ale wręcz ją kreują. Dzięki nimi ukraczamy „,...] w świat wydarzeń, historii, kultury i idei wytuarzanych w nie oparciu o ulegające ciągłym zmianom, pełne sprzeczności rzeczywiste doświadczenie, lecz produkowanych jako artefakty z elementów kodów za pomocą

\footnotetext{
${ }^{16}$ Ibidem, s. 24.

17 J. Baudrillard, Symulakry i symulacja, Wydawnictwo Sic!, Warszawa 2005, s. 5.

${ }_{18}$ Ibidem, s. 20-21.

${ }_{19}$ Por. A. Smrokowska-Reichman, Ekwiwalentne wartości, totalna komunikacja, „Principia” 2008, t. 50, s. 277.

${ }^{20}$ J. Baudrillard, Społeczeństwo konsumpcyjne, jego mity i struktury, Wydawnictwo Sic!, Warszawa 2006, s. 47.

${ }^{21}$ Ibidem, s. 46-47.

22 Ibidem, s. 121-169.
} 
technicznych manipulacji medium”23. Natłok tych przekazów, ich zwielokrotniona ekspozycja pozbawia nas możliwości interpretacji. Znaczenie staje się drugorzędne względem samego przekazu. Znaki stają się jedynie pustą formą, która nie odsyła nas do żadnej idei. „Wydarzenia nie wywołują żadnych konsekwencji, jako że zachodzą zbyt szybko"24. W tym świecie ocena praudziwości jest zausze uzględna. Prawda i kłamstwo stają się jedynie elementami gry pozorów.

\section{wPolityce.pl}

Portal internetowy wPolityce.pl poustał w 2010 roku. Założycielami byli bracia Michał i Jacek Karnowscy. W czerwcu tego samego roku pojawił się tam artykuł pt. wPolityce.pl: myślace, poważne i wolne miejsce rozmowy o Polsce, w którym Michał Karnouski wymienia najważniejsze założenia nowej inicjatywy:

Ma to być miejsce: całkowicie niezależne, wolne od krępujących ograniczeń kapitałowo-politycznych, nie powielające pustych informacji, ale dostarczające wiedzy o wydarzeniach i mechanizmach życia publicznego; wolne od chamstwa i anonimowej agresji; myślące; dynamiczne i nowoczesne; rozwijające się; dostosowane do nowych nawyków korzystania z mediów budujące społeczność; mające swoje zdanie, ale szanujące poglądy innych, ciekawe świata; pokazujące, co napraudę ważne, a co nie warte uwagi; krytyczne wobec partyjnej nowomowy; sprawdzające zgodność deklaracji polityków z ich czynami; pamiętające o polskich obowiązkach wobec państwa, narodu, społeczeństwa; szanujące religię i tradycję; optymistyczne, bo Polskę można kochać z uśmiechem, a dziennikarstwo uprawiać bez żółci²5.

W 2012 powstał związany z portalem durutygodnik „wSieci”, który po kliku wydaniach przekształcił się w tygodnik. W marcu 2017 nakład czasopisma wynosił prawie 140 tysięcy egzemplarzy, co sytuuje go w czołówce tygodników opinii.

W 2016 roku, według raportu Instytutu Monitorowania Mediów, portal wPolityce.pl uzyskał drugie miejsce w klasyfikacji dotyczącej najbardziej opiniotwórczych mediów internetouych w Polsce ${ }^{26}$. Wyprzedził go tylko serwis Onet.pl. Niebagatelnie wysoką pozycję uzyskał też w badaniach dotyczących popularności serwisów tygodników opinii (jako serwis związany z wydaunictuem „wSieci”) - drugie miejsce pod względem liczby zarejestrowanych użytkouników (na pierwszym miejscu Newsweek.pl) i pierwsze pod względem liczby odsłon i czasu korzystania ${ }^{27}$.

\footnotetext{
${ }^{23}$ Ibidem, s. 164.

24 J. Baudrillard, Gorace malarstwo, skazany obraz, „Magazyn Sztuki” 1995, nr 6/7, s. 252.

${ }_{25}$ M. Karnouski, wPolityce.pl: myślace, poważne $i$ wolne miejsce rozmowy o Polsce, http:// wpolityce.pl/polityka/104005-upolitycepl-myslace-powazne-i-wolne-miejsce-rozmowy-o-polsce (dostęp: 20.04.2017).

${ }^{26}$ Najbardziej opiniotwórcze polskie media w 2016 roku, http://www.imm.com.pl/sites/ default/files/raporty/najbardziej_opiniotworcze_media_w_2016_0.pdf (dostęp: 20.04.2017).

${ }^{27}$ http://wuw.wirtualnemedia.pl/artykul/tygodniki-opinii-w-internecie-newsweek-pl-wpolityce (dostęp: 20.04.2017).
} 


\section{Post-prawda, postmodernizm - wpolityce.pl}

Wyrażenie postprawda (pisane łącznie) do końca kwietnia 2017 roku pojawiło się na stronach serwisu w niespełna duudziestu artykułach. Kontekstowe użycie tego neologizmu uskazuje uyraźnie ambiwalentny stosunek dziennikarzy do samej jego definicji.

Z jednej strony publicyści doceniają możliwość retorycznego użycia post-prawdy jako narzędzia w walce z politycznymi oponentami. Strategia ta opiera się między innymi na uskazywaniu zależności post-prauda - postmodernizm - postpolityka - postkomunizm.

Tylko teatr postpraudy, postmodernizmu, relatywizmu może się liczyć. Touarzyszy mu wizja zmiany myślenia społeczeństwa. Do tego jest potrzebne - idąc z Antonio Gramscim opanowanie mediów, uniwersytetów i kultury. W ten sposób zdobywa się władzę i przerabia społeczeństwa ${ }^{28}$.

Tak rozumiana post-prawda okazuje się wyłączną domeną mediów i polityków o poglądach innych niż konserwatywno-prawicowe.

W mediokracji i dyktaturze postprawdy liczy się obrazek, hasztag i granie na najniższych emocjach. Grzegorz Schetyna dobrze o tym wie. Zapędzający go do boju dziennikarze z Czerskiej tym bardziej ${ }^{29}$.

Drugie podejście jest związane z oficjalną wykładnią przedstawioną przez autorów słownika oksfordzkiego oraz najczęściej uskazanymi przykładami jej zastosowania.

Szok opiniotwórczych ośrodków Zachodu wywołały: Brexit, zwycięstwo Trumpa, a wcześniej sukces Fideszu i PiS. Elity naszego świata każdą swoją klęskę muszą tłumaczyć obłędem zbiorowości manipulowanej przez «populistów» i «demagogów» [... Czy przypadkiem to nie te same elity wraz z Derridą dekonstruowały peuniki naszej cywilizacji? [...] Serwowana nam dzisiaj opowieść o postprawdzie jest wielką operacją propagandową i manipulacją, która może przynieść dodatkowe, ponure konsekuencje ${ }^{30}$.

Cytowany tu Bronisław Wildstein podstawowe zagrożenie związane z interesującym nas neologizmem widzi nie w samej jego definicji, a w przykładach do niej dołączonych. Problem zuiązany jest, zdaniem redaktora, z brakiem obiektywizmu ludzi, którzy, tak jak dziennikarze renomowanego „The Economist”, jako przykład post-prawdy podają wiarę $\mathrm{w}$ smoleński zamach. Znamienne jest, że dziennikarz wPolityce.pl, w tym samym

${ }^{28}$ K. Kunert, NASZ WYWIAD, http://wpolityce.pl/kultura/329070-nasz-wywiad-aktorzy-bolly-i-mielski-najpierw-smierc-i-dziewczyna-teraz-klatwa-to-przejawy-tworczej-impotencji (dostęp: 20.04.2017).

${ }^{29}$ Ł. Aamski, Silowe wyniesienie polityków PO z sali to marzenie opozycji. W mediokracji wygrywa „postprawda”, https://wpolityce.pl/polityka/322992-silowe-wyniesienie-politykow-po-z-sali-to-marzenie-opozycji-u-mediokracji-wygrywa-postprauda (dostęp: 20.04.2017).

${ }^{30}$ B. Wildstein, O postprawdzie. Elity naszego świata każdą swoją klęskę muszą tłumaczyć obtędem zbiorowości, http://wpolityce.pl/polityka/336749-o-postpraudzie-elity-naszego-swiata-kazda-swoja-kleske-musza-tlumaczyc-obledem-zbiorowosci (dostęp: 20.04.2017). 
artykule powołuje się na nieistniejące u rzeczywistości ustalenia naukowców (oczywiście bez uskazania źródeł czy nazwisk), które miałyby potwierdzać tezę o eksplozji samolotu w powietrzu. W ten sposób, paradoksalnie, post-prawda staje się narzędziem w walce z zarzutem stosowania post-prawdy.

Jak się okazuje, dużo większą użyteczność retoryczną dla prawicowych dziennikarzy ma pojęcie postmodernizm - rozumiane zarówno jako nazwa tendencji (prawie zausze ocenianych negatyunie) w sztuce, jak i synonim ponowoczesności. Publicyści wPolityce.pl z łatwością odnajdują w nim źródło wszelkiej degrengolady31.

Najpierw postmodernizm a teraz posthistoria i postpolityka. Rodzi się pytanie - czy również postrozum? Mainstreamy światowe promują oczywiście nowe trendy w kulturze. Tak więc i postkultura rozwija się $\mathrm{w}$ najlepsze ${ }^{32}$.

Dla prawicowych publicystów przedrostek post- staje się wygodną etykietą, pozwalającą w jednym worku (pojęć nienawistnych) upchnąć nawet skrajnie odmienne terminy i idee. Oczywiście bagaż ten obciąża uyłącznie domniemanych przeciuników tradycyjnych wartości. „Są wśród tych postępouców przedstawiciele wszystkich warstu społecznych, przesiąknięci wiarą w siłę wyższą, jaką jest neoliberalizm, postpolityka i postmodernizm”33. Wszyscy oni są wyznawcami jednej uspólnej prymitywnej idei mają swoją „Biblię” - „której prawa i przykazania nawiązują do czasów barbarzyństua ludzkości"34. W dalszej części autorka nie sili się na żadne uzasadnienia czy niuanse. Lewicowi bezbożnicy odpowiadają za całe zło - włączając $w$ to kebaby, taniec na rurze, feminizm i seksizm jednocześnie. Choć wyrażenie postprawda nie pojawia się w treści cytowanego artykułu, to autorka, jako przyczyny zagubienia młodego pokolenia, wskazuje właśnie manipulacje medialne oraz fałszywe ideologie.

Jako termin filozoficzny, postmodernizm nie wymaga rozbudowanych definicji, stając się słowem-kluczem, symbolem zgniłej i z gruntu fałszywej ideologii, reprezentowanej przez skompromitowanych filozofów (tu najczęściej pojawia się Zygmunt Bauman) $)^{35}$, których ukrytym celem jest krzewinie idei komunistycznych, demontaż koncepcji państua narodowego oraz walka z chrześcijaństuem ${ }^{36}$.

Odcięcie się od historii, od wielkich historycznych narracji i marsz w kierunku relatywizacji tego wszystkiego co nasza cywilizacja stworzyła w ciągu 2000 lat, jest niczym innym, jak

31 Ibidem.

32 J. Chmielouska, Zaklinanie rzeczywistości ma krótkie nogi, http://wpolityce.pl/polityka/ 172208-zaklinanie-rzeczywistosci-ma-krotkie-nogi-najpierw-postmodernizm-a-teraz-posthistoria-i-postpolityka-rodzi-sie-pytanie-czy-rowniez-postrozum (dostęp: 20.04.2017).

${ }^{33}$ K. Grzybouska, Lewactwo to stan umystu. Ludzie wyposażeni jedynie w mózgi wierza w ideologię. Jaskiniowa, https://wpolityce.pl/spoleczenstwo/330047-lewactwo-to-stan-umyslu-ludzie-wyposazeni-jedynie-w-mozgi-wierza-w-ideologie-jaskiniowa (dostęp: 20.04.2017).

${ }^{34}$ Ibidem.

${ }^{35}$ G. Górny, Z. Bauman jako jeden z przewodników duchowych ludzkości, http://wpolityce. pl/polityka/311277-zygmunt-bauman-jako-jeden-z-przewodnikou-duchowych-ludzkosci (dostęp: 20.04.2017).

${ }^{36}$ K. Grzybouska, Lewactwo to stan umystu..., op. cit. 
odcięciem się od ludzkiego, a nawet ogólnoludzkiego doświadczenia i pozbawieniem go naturalnej immunologicznej obrony. Zabranie zagubionemu człowiekowi dziejowej mądrości czyni go bezbronnym. Ba, to nakręcanie wojny każdego z każdym [...] Postmodernizm odcina dostęp do ludzkiej refleksji, a więc u ten sposób otumania człowieka i czyni go niezdolnym do żadnej obrony ${ }^{37}$.

Na szczęcie na straży naszego bezpieczeństwa czuwają ci, których nie udało się omamić - dziennikarze portalu wPoltyce.pl. Ich tarczą są konserwatywne wartości, orężem zaś prawda. Wprost trudno sobie uyobrazić, co by się stało, gdyby i ich dotknęła ta „ponowoczesna zaraza”, gdyby post-prawda zastąpiła praudę. Dobrze, że ta ostatnia jest apriorycznie przypisana do zwolenników prawicy i nie trzeba nawet spraudzać jej źródeł [Sic!]. Co ciekawe, owa zasada nie dotyczy wyłącznie Polski:

«Fake news» i postprawda, te dwa słowa elektryzują opinię publiczną praktycznie na każdym z kontynentów. W Stanach Zjednoczonych wojnę mediom rozpouszechniającym fałszywe informacje wypowiedział Donald Trump ${ }^{38}$.

Dziennikarzom wPolityce.pl nie przeszkadza, że to właśnie uypowiedzi prezydenta USA są podawane najczęściej jako przykłady post-prawdy. Można bowiem założyć, że jako konserwatysta mówi praudę, a mylą się lub świadomie kłamią uszyscy, którzy podważają jego wiarygodność.

Człowiek kontrowersyjny tym się różni od hipokrytów, że posługuje się praudą, mówi to co myśli, nie ukrywa swoich poglądów, w tym wiedzy o otaczającej go rzeczywistości. Tak się zachouuje prezydent USA Donald Trump, za co amerykańscy i europejscy hipokryci go nienawidzą ${ }^{39}$.

Ta nienawiść zdaje się przyćmiewać prawdę ogólną, która, jak się okazuje, nie zausze musi być zgodna z faktami.

\section{Krótkie zakończenie}

Jak poucza lektura portalu analizowanego serwisu - „«brudne», antychrześcijańskie, antykatolickie, antynarodowe, barbarzyńskie, lewackie, destrukcyjne ideologie rodzą brud” ${ }^{40}$. Ich wspólnym znakiem okazuje się prefiks post-. Procesje „post-neologizmów”

37 R. Surmacz, Idzie nowe, http://wpolityce.pl/polityka/162755-idzie-nowe-tylko-lemingi-jakos-
-nie-moga-zrozumiec-ze-ich-sztuczny-suiat-konczy-sie-i-ze-musi-byc-inaczej (dostęp: 20.04.2017).
38 Szwedzi chca się bronić przed "fake news". W szkołach dzieci będa się uczyć analizy
informacji, https://wpolityce.pl/spoleczenstwo/331629-szwedzi-chca-sie-bronic-przed-fake-
-news-w-szkolach-dzieci-beda-sie-uczyc-analizy-informacji (dostęp: 20.04.2017).
39 K. Grzybowska, Sa tak głupi, że nawet o tym nie wiedza. Amerykańscy i europejscy
hipokryci nienawidza Trumpa, https://wpolityce.pl/polityka/329105-sa-tak-glupi-ze-nawet-o-
-tym-nie-wiedza-amerykanscy-i-europejscy-hipokryci-nienawidza-trumpa (dostęp: 20.04.2017).
40 K. Nagrodzki, Z listu do przyjaciót. I znajomych. Jak wielkie, stare drzewo..., wpolityce.pl/
lifestyle/320003-z-listu-do-przyjaciol-i-znajomych-jak-wielkie-stare-drzewo (dostęp: 20.04.2017). 
rozpoczął prawdopodobnie postmodernizm, który przybrany u szaty nowoczesności, pod płaszczykiem poprawności politycznej i dyskursu równościowego, ukrywał starego, dobrze znanego wroga - komunizm, czy może lepiej powiedzieć - postkomunizm. Kolejne zainfekowane formy ludzkiej działalności, dla przestrogi, przybierały formy neologizmów - zrostów wyrazowych, których poutarzający się początek degradował idee stojące za pochłoniętymi rzeczownikami. Wszystkie one w rzeczywistości stały się reprezentacją uspólnego ideografu ${ }^{41}$. Ideagrafu, który stanowi element retoryki konstytutyunej nie tylko portalu wPolityce.pl, ale większości polskich mediów prawicowo-konserwatywnych ${ }^{42}$. Jest nim płynna nowoczesność wraz zawartą weń koncepcją społeczeństua - tak różną od wzorca Polaka-katolika, że można ją uznać za reprezentacje idei wroga.

\section{Bibliografia}

Aamski Ł., Siłowe wyniesienie polityków PO z sali to marzenie opozycji. W mediokracji wygrywa „postprawda”, https://wpolityce.pl/polityka/322992-silowe-wyniesienie-politykow-po-z-sali-to-marzenie-opozycji-w-mediokracji-wygrywa-postprawda (dostęp: 20.04.2017).

Barańska E., Kultura ponowoczesna w myśli Baumana, Wydawnictwo Adam Marszałek, Toruń 2016.

Baudrillard J., Gorace malarstwo, skazany obraz, „Magazyn Sztuki”, 1995, nr 6/7.

Baudrillard J., Społeczeństwo konsumpcyjne, jego mity i struktury, Wydaunictwo Sic!, Warszawa 2006.

Baudrillard J., Symulakry i symulacja, Wydawnictwo Sic!, Warszawa 2005.

Bendyk E., Odzyskiwanie sensu, http://www.polityka.pl (dostęp: 20.04.2017).

Chmielouska J., Zaklinanie rzeczywistości ma krótkie nogi, http://wpolityce.pl/polityka/172208-zaklinanie-rzeczywistosci-ma-krotkie-nogi-najpierw-postmodernizm-a-teraz-posthistoria-i-postpolityka-rodzi-sie-pytanie-czy-rowniez-postrozum (dostęp: 20.04.2017).

Chmielewski A., Post-prawda i populizm prawdziwościowy, http://www.academia. edu/31567577/POST-PRAWDA_I_POPULIZM_PRAWDZIWO\%C5\%9ACIOWY_1 (dostęp: 20.04.2017).

Giddens A., Konsekwencje nowoczesności, Wydawnictuo Uniwersytetu Jagiellońskiego, Kraków 2008.

Górny G., Z. Bauman jako jeden z przewodników duchowych ludzkości, http://upolityce. pl/polityka/311277-zygmunt-bauman-jako-jeden-z-przewodnikow-duchouych-ludzkosci (dostęp: 20.04.2017).

Grzybouska K., Lewactwo to stan umystu. Ludzie wyposażeni jedynie w mózgi wierza w ideologię. Jaskiniowa, https://wpolityce.pl/spoleczenstwo/330047-lewactwo-to-stan-umyslu-ludzie-wyposazeni-jedynie-w-mozgi-wierza-w-ideologie-jaskinioua (dostęp: 20.04.2017).

${ }^{41}$ Por. M.C. McGee, The „ideograph”. A link between rhetoric and ideology, „Quarterly Journal of Speech" 1980, nr 66, s. 1-16.

${ }^{42}$ Por. P. Kozielski, O chorobie Rzeczypospolitej, jaka jest propornograficzna seksedukacja wprawka do analizy dyskursu prasowego „Gazety Polskiej”, „Ars Educandi” 2014, T. XI. 
K. Grzybouska, Sa tak głupi, że nawet o tym nie wiedzą. Amerykańscy i europejscy hipokryci nienawidza Trumpa, https://wpolityce.pl/polityka/329105-sa-tak-glupi-ze-nawet-o-tym-nie-wiedza-amerykanscy-i-europejscy-hipokryci-nienawidza-trumpa (dostęp: 20.04.2017).

http://wuw.wirtualnemedia.pl/artykul/tygodniki-opinii-w-internecie-newsweek-pl-wpolityce (dostęp: 20.04.2017).

Jenkins S., Post-truth politics will be debunked by online facts, https://www.theguardian. com/commentisfree/2017/jan/26/post-truth-politics-online-facts-donald-trump-lies (dostęp: 30.04.2017).

Karnouski M., wPolityce.pl: myślace, poważne i wolne miejsce rozmowy o Polsce, http://upolityce.pl/polityka/104005-wpolitycepl-myslace-powazne-i-wolne-miejsce-rozmowy-o-polsce (dostęp: 20.04.2017).

Keyes R., The Post-Truth Era: Dishonesty and Deception in Contemporary Lifes, St. Martin's Press, New York 1992.

Kozielski P., O chorobie Rzeczypospolitej, jaka jest propornograficzna seksedukacja - wprawka do analizy dyskursu prasowego „Gazety Polskiej”, „Ars Educandi” 2014, T. XI.

Kunert K., NASZ WYWIAD, http://wpolityce.pl/kultura/329070-nasz-wywiad-aktorzy-bolly-i-mielski-najpierw-smierc-i-dziewczyna-teraz-klatwa-to-przejawy-tworczej-impotencji (dostęp: 20.04.2017).

Lyotard F.J., Kondycja ponowoczesna. Raport o stanie wiedzy, Fundacja Aletheia, Warszawa 1997.

Lyotard F.J., Postmodernizm dla dzieci. Korespondencja 1982-1985, Fundacja Aletheia, Warszawa 1998.

McGee M.C., The „ideograph”: a link between rhetoric and ideology, „Quarterly Journal of Speech" 1980, nr 66.

Nagrodzki K., Z listu do przyjaciót. I znajomych. Jak wielkie, stare drzewo..., wpolityce.pl/lifestyle/320003-z-listu-do-przyjaciol-i-znajomych-jak-wielkie-stare-drzewo (dostęp: 20.04.2017).

Najbardziej opiniotwórcze polskie media w 2016 roku, http://www.imm.com.pl/sites/default/ files/raporty/najbardziej_opiniotworcze_media_w_2016_0.pdf (dostęp: 20.04.2017).

Rorty R., Przygodność, ironia i solidarność, Wydawnictwo W.A.B., Warszawa 1996.

Smrokouska-Reichman A., Ekwiwalentne wartości, totalna komunikacja, „Principia” 2008, t. 50.

Surmacz R., Idzie nowe, http://wpolityce.pl/polityka/162755-idzie-nowe-tylko-lemingi-jakos-nie-moga-zrozumiec-ze-ich-sztuczny-swiat-konczy-sie-i-ze-musi-byc-inaczej (dostęp: 20.04.2017).

Szuedzi chca się bronić przed "fake news". W szkołach dzieci będa się uczyć analizy informacji, https://wpolityce.pl/spoleczenstwo/331629-szwedzi-chca-sie-bronic-przed-fake-news-w-szkolach-dzieci-beda-sie-uczyc-analizy-informacji (dostęp: 20.04.2017).

Tesich S., A Government of Lies, „The Nation” 1992 (January).

Wildstein B., O postprawdzie. Elity naszego świata każda swoją klęskę musza ttumaczyć obtędem zbiorowości, http://wpolityce.pl/polityka/336749-o-postprawdzie-elity-naszego-swiata-kazda-swoja-kleske-musza-tlumaczyc-obledem-zbiorowosci (dostęp: 20.04.2017).

Word of the year 2016, https://en.oxforddictionaries.com/word-of-the-year/word-of-the-year-2016 (dostęp: 12.04.2017). 